10.53116/pgaflr.2018.1.4

\title{
Concept of Good Governance in Jurisprudence: The Russian Experience and Practice
}

\author{
Elena Kireeva*
}

\begin{abstract}
* Elena Kireeva, Doctor of Legal Sciences, Dean of the Faculty of Personnel Management and Civil Service of the Institute of Public Administration and Civil Service of the Russian Presidential Academy of National Economy and Public Administration, Russian Federation. She is a member of the Advisory Board of the Higher Attestation Commission under the Ministry of Education and Science of the Russian Federation. She is the author of three books and more than 45 reviewed articles in prestigious journals. (e-mail: elena_kireeva02@mail.ru)
\end{abstract}

\begin{abstract}
In the given contribution the author analyses the Russian experience in the implementation of the concept of good governance. The research highlights the issues in the sphere of public management, which have been only partially resolved in the course of the administrative reform in the Russian Federation. Using the method of comparative legal analysis and monitoring the author reviews the existing approaches to the concept of good governance in the scientific literature and explores the implementation of the principles of good governance enshrined in the EU documents in the Russian law.
\end{abstract}

Keywords: good governance; good administration; modern bureaucracy

\section{Introduction}

In this article the author presents the results of an analysis of the implementation of the principles of good governance declared in the governing documents of the Council of Europe in the national legislation of the Russian Federation.

On the basis of the methods of systematic comparative legal analysis and monitoring, the study of normative regulation of activities of executive bodies of the Russian Federation the author reveals the effect of such principles as transparency and the rule of law.

\section{Analysis of the Situation in the Russian Federation}

According to a number of experts, formalization of relations is one of the sides of bureaucracy. Being a complicated social phenomenon, bureaucracy is explored by political scientists and government officials and is practically not included in the legal categories. ${ }^{1}$

There is also an opposite position claiming that it's been a long time since the historical process of bureaucracy development demonstrated a number of features of this phenomenon, including its trend towards self-expansion and a tight connection with the regulatory self-description, i.e. association with the principle of legality. ${ }^{2}$

In the research of issues related to bureaucracy as part of public administration and administrative law the emphasis is firstly on the sphere of executive power. 
How did the executive power in Russia transform in the recent years, what are the top priorities of the administrative reforms?

As it's been noted by the experts from the Institute of Comparative Legislation under the Government of Russia, an important direction of administrative reforms is connected with the administrative legal regulation of the mechanism used by the executive bodies exercising their powers. Executive bodies must follow the uniform rules established by law. This order will in many ways contribute to the efficiency and democratic character of the judgements made in public and private cases in this country, as well as to the development of a modern system of executive power. ${ }^{3}$

In addition to the settlement of administrative procedures there was a task to develop administrative procedures that would regulate the fulfilment of all state functions and certain processes that ensure their fulfilment, including those connected with the provision of state services to the public; with a guarantee of protection of citizens and organizations' rights and duties; with the provision of public services to particular persons in the state bodies. $^{4}$

Evaluating the practical results of the administrative reforms in facts and figures one should note the following:

- federal bodies of executive power have developed over 400 administrative policies of public services provision;

- 232 policies have been approved and registered in the Ministry of Justice of the Russian Federation;

- over 40 subjects of the Russian Federation have adopted their legal framework of policies and continue their development;

- the total number of administrative policies adopted at the level executive bodies of the subjects of the Russian Federation is over 2,000.5

In addition to regulatory policies, active work has been done on the development of information support of public administration.

Based on the Russian Government Decree of 25 December 2009 no. 1088 (as amended on 27 November 2015) state automated information system "Administration" (Rus. "Upravleniye") was created. ${ }^{6}$

SAS "Administration" is a unified distributed state information system that provides collection and procession of the data contained in state and municipal information resources, official statistics, and the data for making management decisions in the sphere of public administration, including the information support of strategic planning, as well as the provision and analysis of the data in accordance with the relevant decree.

The state automated information system "Administration" was created in order to increase the efficiency of public administration and to deal with the following tasks:

a) provision of informational and analytical support to the decision-making bodies of the state and local self-governments, as well as planning the activities of these bodies;

b) monitoring, analysis and control of the execution of the decisions made by the bodies of state and local power of the Russian Federation, including the strategic planning decisions and top priority national projects; 
c) monitoring and analysis of the processes occurring in the real sector of economy, finance, banking and social spheres, as well as social and economic development of the constituent territories of the Russian Federation;

d) assessment of the efficiency of the activity of the executive bodies of the Russian Federation and local self-governments;

e) monitoring, analysis and control over the achievement of target indicators stipulated in the Decrees of the President of Russia of 7 May 2012 no. 596-606 for the constituent territories of the Russian Federation, as well as the implementation of measures aimed at their achievement;

strategic planning support in:

- state registration of the documents of strategic planning;

- maintaining the state federal registry of documents of strategic planning;

- monitoring and control of implementation of documents of strategic planning in accordance with the established procedure;

- monitoring and controlling indicators of social and economic development and protection of Russian Federation national security;

- monitoring the efficiency of work of strategic planning participants;

- providing participants of strategic planning participants, entities and individual with an access to the documents of strategic planning;

- development of public hearings and approval of the drafts of strategic planning documents in accordance with the established procedure;

- information and analytical support of strategic planning participants in fulfilment of strategic tasks.

SAS "Administration" contains the data on 8.5 thousand indicators. The list of indicators is formed by means of coordination of operation flow charts of interdepartmental interaction with the help of the portal of methodological support of SAS "Administration" project development.

For the citizens of the Russian Federation the practical result of the administrative reform is the creation of a portal of public services and a chain of multi-functional centres providing state and municipal services (MFC), which simplified considerably the interactions with the state bodies aimed at the receipt of a number of documents and other public services.

As it has been noted by the colleagues from the Institute of Comparative Legislation, more and more measures facilitating the access to public services are introduced in the legislation. The terms of entering market relations are simplified. For example, there is a transition to the notification order of business registration based on a single-window principle within the timeframe established by law. The number of licensable activities has decreased dramatically. The functions of the licensing bodies are regulated by means of removing control and oversight powers over subordinate subjects from their authorities.7

The single-window principle implies that the state or municipal service is provided after a single application with a relevant request. 
As of 1 January 2016, 2,684 centres and 10,130 offices providing state and municipal services were created in Russia. The coverage of the population with the single-window service amounted to over $94 \%$.

The Government of the Russian Federation summarized the results of multifunctional centres creation project. The key results are presented in the report on the progress of the realization of the Decree of the President of Russia of 7 May 2012 no. 601 "On the Main Direction in Improving the Public Administration System". According to the data of monitoring the development of MFC network, as of 1 March 2017, 2,777 multi-functional centres, 10,214 autonomous units and 312 offices on the basis of contractors had been created in Russia. Over 33,000 of multifunctional specialists are employed by them all over the country. About 350,000 citizens of Russia apply to multifunctional centres for advice or services per day. Over 60 million services were provided in multi-functional centres in $2016 .^{8}$

As of 1 March 2017, the indicator of population coverage by the single-window system, calculated on the basis of the methodology approved at the Government Committee hearing concerning the implementation of the administrative reform of 30 October 2012 no. 135, amounted to $96.6 \%$ of the total population of the Russian Federation.

Regular social studies have shown that the average waiting time for the citizens applying for state and municipal services is decreasing steadily: in 2012 this indicator was 55 minutes; in 2013 - 52 minutes; in 2014 - 42 minutes; in 2015 - 35.7 minutes; in 2016 - 21.9 minutes. About $49.1 \%$ of the respondents noted that they had spent less than 15 minutes in the queue waiting for their turn to submit the documents in order to receive state and municipal services. The results of the research show that the waiting time in MFC is less than in the bodies of public authority and self-government bodies and is evaluated by the respondents at 18.9 minutes.

Analysing the results of the transformations many Russian colleagues speak of low efficiency of the reform. Thus, for example, A.M. Gogolev emphasizes that the course of the administrative reform is contradictory and that it is dragged out. ${ }^{9}$ He points out that the key "consumer" of the reform at present is the entrepreneurial environment. And one of the key components of the reform is the orientation at the efficient service for this environment. The functional differentiation of federal executive bodies shows that the reform is aimed at the so-called new models of public administration that have already been implemented in other countries by liberal reformers. The transition to the new form of public administration is taking place under the conditions that are either absent or in their infancy in Russia.

Director of the Institute of Legislation and Comparative Legal Studies under the Government of the Russian Federation T.Y. Khabrieva underlines that the absence of a systemic approach to the regulation of administrative procedures leads to a situation where many of them will start either working inefficiently or translate into administrative barriers that impede the exercise of rights and freedoms and the solution of economic and political tasks faced by the state and society. ${ }^{10}$

The source, or the "breeding ground" for the administrative barriers could be the loopholes in the legislation, as well as excessive regulation, which is proved by the practice 
of enforcement of numerous regulations related to the execution of public functions and provision of public services. ${ }^{11}$

Early in the '80s of the last century EU countries kickstarted the work on the assessment and removal of excessive administrative control. The given activity that was called "de-regulation" was determined by the need to reinforce the role of small business as the most active sector of economy. In the middle of the '90s the CIS countries joined this activity, too. In Russia the stable trend towards the reduction of administrative burden emerged early in this century. ${ }^{12}$

A. M. Gogolev highlighted two strategies of reforms implementation. The first strategy makes entrepreneurship the top priority and sees it as the only unifying force in the face of radical social changes. The second one relies on the liberal concept of the priority of the civil society over the state and views public administration as a purely auxiliary tool, while the key goal of the reform is to turn public administration into a transparent and efficient institute providing service to the person and to the citizen. The reform implementation must involve the institutes of social control and the necessity for wide public debates.

Today the basis of the reform efforts should be the change in the relationships between the state and the citizen, where the state should be given the role of a kind of service centre, safeguarding the interests of a person and a citizen, while the administrative law should fulfil the function of legal support of this activity. The given position seems quite relevant and viable for modern Russia.

\section{The Concept of Good Governance and Its Russian Interpretation}

The term "good governance" has become quite popular in the legal doctrine recently, which is confirmed by numerous publications and the enshrinement of the given principle in international acts and national legislation.

As it has been noted by Professor Igor Bartsits, the very term "good governance" (Spanish "buen gobierno", French "bonne gouvernance") is quite widespread. There is a Canadian political maxim "Peace, order and good governance", which places good governance in one row with such unconditional values as peace and order. ${ }^{13}$

Professor I. V. Ponkin considers good governance in terms of three key aspects:

1. as a measure of ideal in public administration;

2. as a concept of design, development, realization and assessment of public administration;

3. as a tool system.

The first case refers to the ideal quality of the system of public administration that is in public demand.

The second one refers to the value-laden regulatory concept describing "good governance", including the systemic totality of formal rules (laws and by-laws) and nonformal propositions (corporate and social norms), regulating the conduct of individuals 
and organizations and guiding the managerial activity. The concept also includes the ideas, the tools for their implementation and the system of essential attributes (and at the same time criteria) of quality of public administration and expected (designed) quality indicators of public administration.

As a tool system "good governance" is a structural and functional totality of institutional, legal, organizational and administrative mechanisms of design, programming, realization, provision and control of public administration with the aim of providing, protecting and safeguarding public interests, realizing social, economic and other functions of public power, including the provision of sustainable wealth of all the citizens, security of an individual, of the society and the state, stability of the positive and efficient economic development of the state. ${ }^{14}$

To our opinion one can simplify all of the constructions mentioned above by leaving Cicero's formula that is as old as time, "Salus populi suprema lex esto" and determine the wealth of the people to be the main appraisal criterion of public authority's activity.

It should be noted that in the Russian legal doctrine, as well as in the legislation, the term "good governance" is not a widely spread one yet, while its separate elements or principles are used in the regulatory framework, e.g. executive and local self-government bodies' performance indicators have been established, guaranteed access to the information about the activity of public authorities has been enshrined, as well as the defence of economic entities' rights in the course of state and municipal control, the principles of electronic government activity and the use of electronic document flow in the activity of public authorities.

\section{Good Governance in International Documents}

As it has been noted by Professor I. V. Ponkin, at present the term "good governance" has become a permanent part of the vocabulary of a wide range of participants of the international community. Today almost all major institutes declare that "good governance" is their priority and a part of their development strategy. ${ }^{15}$

Article 41 "Right to good administration" of the Charter of Fundamental Rights of the European Union (2007/C 303/01) (Strasbourg, 14.12.2007) ${ }^{16}$ declares:

1. Every person has the right to have his or her affairs handled impartially, fairly and within a reasonable time by the institutions, bodies, offices and agencies of the Union.

2. This right includes:

(a) the right of every person to be heard, before any individual measure which would affect him or her adversely is taken;

(b) the right of every person to have access to his or her file, while respecting the legitimate interests of confidentiality and of professional and business secrecy;

(c) the obligation of the administration to give reasons for its decisions. 
3. Every person has the right to have the Union make good any damage caused by its institutions or by its servants in the performance of their duties, in accordance with the general principles common to the laws of the Member States.

4. Every person may write to the institutions of the Union in one of the languages of the Treaties and must have an answer in the same language.

The principle of good governance is mentioned in the Stockholm Programme - an Open and Secure Europe serving and protecting citizens (2010/C 115/01) (4.5.2010), “The European Council recalls that transparency of decision-making, access to documents and good administration contribute to citizens' participation in the democratic life of the Union. Furthermore, the Union citizens' initiative introduced by Article 11 TEU will create a new mechanism for civic participation. That mechanism should be realised rapidly" (2.6. Participation in the democratic life of the Union). ${ }^{17}$

P.4 Art. 71 Regulation (EC) No. 883/2004 of the European Parliament and of the Council on the coordination of social security systems (Strasbourg, 29.4.2004) ${ }^{18}$ enshrines that "The institutions, in accordance with the principle of good administration, shall respond to all queries within a reasonable period of time and shall in this connection provide the persons concerned with any information required for exercising the rights conferred on them by this Regulation".

The given principle is also reflected in branch administration. As an example, one can think of Recommendation $\operatorname{Rec}(2005) 8$ "On the principles of good governance in sport" (adopted by the Committee of Ministers on 20 April 2005 at the 924th meeting of the Ministers' Deputies), where it was stipulated that "good governance in sport is a complex network of policy measures and private regulations used to promote integrity in the management of the core values of sport such as democratic, ethical, efficient and accountable sports activities; and that these measures apply equally to the public administration sector of sport and to the non-governmental sector of sports".

Good Governance - the responsible conduct of public affairs and management of public resources - is encapsulated in the Council of Europe 12 Principles of Good Governance. The 12 Principles are enshrined in the Strategy on Innovation and Good Governance at local level, endorsed by a decision of the Committee of Ministers of the Council of Europe in 2008. They cover issues such as ethical conduct, rule of law, efficiency and effectiveness, transparency, sound financial management and accountability: ${ }^{19}$

1. Fair Conduct of Elections, Representation and Participation

2. Responsiveness

3. Efficiency and Effectiveness

4. Openness and Transparency

5. Rule of Law

6. Ethical Conduct

7. Competence and Capacity

8. Innovation and Openness to Change

9. Sustainability and Long-term Orientation

10. Sound Financial Management

11. Human Rights, Cultural Diversity and Social Cohesion 
12. Accountability

\section{Incorporation of the Principles of Good Governance in the Russian Legal System}

Let us consider how the above-mentioned principles can be incorporated into the Russian legal system.

It is obvious that the analysis of the implementation of all 12 principles is not the objective of the given work, so we will dwell only on such an important component as good governance as openness and transparency (4).

The given principle implies that:

- Decisions are taken and enforced in accordance with rules and regulations.

- There is public access to all information, which is not classified for well-specified reasons as provided for by law (such as the protection of privacy or ensuring the fairness of procurement procedures).

- Information on decisions, implementation of policies and results is made available to the public in such a way as to enable it to effectively follow and contribute to the work of the local authority.

Federal law of 09.02.2009 No 8-FZ (as amended on 28 December 2017) "About Ensuring Access to Information on Activities of State Bodies and Local Government Bodies",20 Article 4 "The Main Principles of Ensuring Access to Information on Activities of State Bodies and Local Government Bodies" enshrines the following:

1. openness of information on the activity of state bodies and local self-government bodies and a free access to that information, except for the cases specified under federal laws;

2. the accuracy of information and the timeliness of its provision;

3. freedom of search, receipt, transfer, production and dissemination of information on the activity of state bodies and local self-government bodies by any legal means;

4. observation of citizens' rights to the inviolability of private life, personal and family privacy, their honour and business reputation of citizens as well as the business reputation of organisations in the course of provision of information on the activity of state bodies and local self-government bodies.

The given law establishes some restrictions on the effect of the principles mentioned above in case it constitutes state or other official secret under the legislation of the Russian Federation (Article 5).

Article 8 also declares that the information users shall have the following rights:

1. to receive reliable information on the activities of government bodies and local government bodies;

2. to refuse to receive information on the activities of government bodies and local government bodies; 
3. not to substantiate the need to obtain the requested information on the activities of government bodies and local government bodies, the access to which is not restricted;

4. to appeal in accordance with the established procedure the acts and (or) actions (omissions) of state bodies and local government bodies, their officials, which violate the right to access information on the activities of government bodies and local government bodies and the established procedure for enjoyment thereof;

5. to demand, in accordance with the procedure established by the law, compensation for harm caused by violation of his/her right to access to the information on the activities of government bodies and local government bodies.

In the legal system of the Russian Federation there is a separate act on the provision of access to information on the activities of the courts. Federal law of 22.12.2008 No 262-FZ (as amended on 28 December 2017) "On provision of access to information on the activities of courts in the Russian Federation" 21 envisages the following ways of access to the information on the activities of courts:

1. presence of citizens (individuals), including representatives of organizations (legal entities), public associations, public authorities and local self-government bodies, in an open court session;

2. disclosing (publishing) information on the court activities in the mass media;

3. posting information on the court activities in the Internet;

4. placement of information on the court activities in the premises occupied by the courts, the Judicial Department, the bodies of the Judicial Department, and the bodies of the judiciary;

5. familiarization of information users with the information retained in archives;

6. providing information users upon their request with information on the activities of the courts;

7. webcasting open court sessions on the Internet in accordance with this Federal Law, other federal laws (Article 6).

The Resolution of the Plenum of the Supreme Court of the Russian Federation of 13.12.2012 no. 35 "On the openness and publicity of legal proceedings and about information access about activity of the courts" 22 enshrines that the openness and publicity of legal proceedings, timely, qualified, objective informing society on the activity of the courts of the general jurisdiction contribute to an increase in the level of legal awareness of judicial system and legal proceedings, are a guarantee of fair legal proceedings, and also provide public control over functioning of judicial authority. Open legal proceedings are a means of maintaining the society's trust in court.

The openness and publicity of legal proceedings, access to the information about the activity of courts shall promote the realization of tasks of civil, administrative and criminal trial (Article 2 CCP of the Russian Federation, Article 24.1 of the Code of the Russian Federation on Administrative Offences, Article 6 of the Code of Criminal Procedure of the Russian Federation) and shall not lead to any intervention in judicial activities, as courts implementing justice are independent and submit only to the Constitution of the 
Russian Federation and the law (Article 120 of the Constitution of the Russian Federation, Article 5 of the Federal constitutional law "About Judicial System of the Russian Federation", Item 5 Article 4 of the law on ensuring access to information).

\section{Conclusion}

The concept of good governance in the Russian Federation has formed mainly in the managerial and administrative legal doctrine.

Some of its elements or principles are used in the regulatory framework, e.g. executive and local self-government bodies' performance indicators have been established; guaranteed access to the information about the activity of public authorities has been enshrined, as well as the defence of economic entities' rights in the course of state and municipal control, ${ }^{23}$ and a number of others.

A considerable amount of work aimed at the provision of legal regulation of executive bodies' activity in terms of public functions fulfilment (including the provision of public services to individuals and legal entities) has been done in the Russian Federation.

A lot of attention is given to the regulation of administrative procedures, the development of administrative policies and forms of interaction, including the online one, between the public authorities.

A legal framework and electronic resources ensuring the interaction of the system of state power with the external environment have been developed, among which there are such state automated systems as "Administration", "Justice", "Elections", public services, Federal Tax services portals, etc.

The percentage of the population using electronic services has increased; the time of their provision has decreased.

However, a lot of administrative barriers have not been removed yet; the paper-flow and reporting forms have grown massively (online reports have been added to the paper ones); there is excessive regulation of a number of administrative processes (e.g. lengthy interdepartmental approval of documents). 


\section{References}

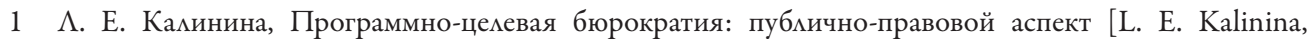
Special-Purpose Bureaucracy: Legal and Public Aspect], 11-14, іn Государственная власть и местное самоуправление [State Power and Local Self-Government], no. 10 (2014).

2 И. А. Исаев, Иегальность и бюрократия [I. A. Isaev, Legality and Beraucracy], 3-8, in История государства и права [History of State and Law], no. 20 (2014).

3 Е. К. Волчинская, и Ар., С. Е. Нарышкин, С. Е., Хабриева, Т. Я., ААминистративная реформа в России. Научно-практическое пособие [E. K. Volchinskaya et al., S. E. Naryshkin, T. Y. Khabrieva (eds.), Administrative Reform in Russia. Research and Practice Textbook] (Moscow, Kontrakt, Infra-M 2006).

4 Ibidem.

5 Monitoring Administrative Policies Implementation (National Research University "Higher School of Economics"), monitoring.hse.ru/about (accessed 10 May 2018).

6 Собрание законодательства РФ [Collection of Legislative Acts of the Russian Federation], 4 January 2010, no. 1 , Art. 101.

7 Т. Я. Хабриева, Ж. Марку, ААминистративные процедуры и контроль в свете европейского опыта [T. Y. Khabrieva, Zh. Marku (eds.), Administrative Procedures and Control in the Light of European Experience] (Moscow, Statut 2011).

8 Совершенствование государственного управления: портал административной реформы [Enhancing Public Administration: Portal of the Administrative Reform], http://ar.gov.ru/ru/news/42956/1/0/2/10/ index.html (accessed 10 May 2018).

9 А. М. Гоголев, Некоторые тенденции и закономерности становления и развития государственного администрирования [А. M. Gogolev, Some Trends and Patterns in the Development of Public Administration], 19-25, in Административное право и процесс [Administrative Law and Procedure], no. 2 (2018).

10 Т. Я. Хабриева, Ж. Марку, ААминистративные процедуры и контроль в свете европейского опыта [T. Y. Khabrieva, Zh. Marku (eds.), Administrative Procedures and Control in the Light of European Experience] (Moscow, Statut, 2011).

11 See more in: Аокмад Аепартамента развития малого и среднего предпринимательства Министерства экономического развития Российской Федерации „Об исполнении полномочий по государственному контролю (надзору), муниципальному контролю государственными (муниципальными) предприятиями и учреждениями" [Report of the Department of Small and Medium Business Development of the Ministry of Economic Development of the Russian Federation "On the Execution of Authorities of State Control (Oversight), Municipal Control by State (Municipal) Enterprises and Institutions"] (Moscow 2010).

12 А. А. Истомина и Ар., Малое преАпринимательство: как снизить административные барьеры? Зарубежный опыт. [L. A. Istomina et al., Small Business: How to Reduce Administrative Barriers?] (Moscow, Tesey, 2003).

13 И. Н. Барциц, Конституционное право на хорошее (эффективное) управление: критерии, показатели, оценки [I. N. Bartsits, Constitutional Right to Good (Efficient) Governance: Criteria, Indicators, Evaluation], 64-71, in Конституционное и муниципальное право [Constitutional and Municipal law], no. 11 (2013).

14 И. В. Понкин, Теория пубцичного управления: Учебник мия магистратуры [I. V. Ponkin, Theory of Public Administration: Texbook for Master's Programme], 336 (Moscow 2017)

15 И. В. Понкин, Теория публичного управления: Курс мекций [I. V. Ponkin, Theory of Public Administration: Course of Lectures], 86 (Moscow 2013).

16 Хартия Европейского Союза об основных правах [The EU Charter of Fundamental Rights], www.coe. int/t/ngo/Source/reading_guide_charter_fr.pdf (accessed 10 May 2018). 
17 Стокгольмская программа „Открытая и безопасная Европа, которая служит своим гражданам и защищает их" [The Stockholm Programme - An open and secure Europe serving and protecting the citizens], ec.europa.eu/anti-trafficking/eu-policy/stockholm-programme-open-and-secure-europe-serving-andprotecting-citizens-0_en (accessed 10 May 2018).

18 Регламент $N$ 883/2004 Европейского парламента и Совета Европейского Союза „О координации систем социальной защиты" [Regulation (EC) No 883/2004 of the European Parliament and the Council of 29 April 2004 on the coordination of social security systems], eur-lex.europa.eu/ (accessed on 10.05.2018)

19 Principles of Good Governance and European Label of Governance Excellence (ELoGE), www.coe.int/en/ web/good-governance/12-principles-and-eloge (accessed on 10.05.2018)

20 Собрание законодательства РФ. 2009. № 7. Ст. 776 [Collection of Legislative Acts of the Russian Federation of 4 January 2009, no. 7, Art. 776]

21 Собрание законодательства РФ, 29.12.2008, N 52 (ч. 1), ст. 6217 [Collection of Legislative Acts of the Russian Federation of 29 December 2008, no. 52, part 1, Art. 6217]

22 Бюмметень Верховного Суда РФ. 2013. N 3, март [Bulletin of the Supreme Court of the Russian Federation of 2013, no. 3, March]

23 Федеральный закон от 26.12.2008 N 294-Ф3 (ред. от 18.04.2018) „О защите прав юридических миц и индивидуальных предпринимателей при осуществлении государственного контроля (надзора) и муниципального контромя" [Federal Law of 26.12.2008 No 294-FZ as amended on 18 April 2018 "On protection of rights of legal entities and individual entrepreneurs in exercise of state control (supervision) and municipal control”), Собрание законодательства РФ. 2008. N 52 (ч. 1), ст. 6249 (Collection of Legislative Acts of the Russian Federation. 2008, no. 52, part 1, Art. 6249] 